\title{
Retracted: Cashew Nut Shell Waste: Availability in Small-Scale Cashew Processing Industries and Its Fuel Properties for Gasification
}

\author{
ISRN Renewable Energy \\ Received 16 September 2013; Accepted 16 September 2013 \\ Copyright (C) 2013 ISRN Renewable Energy. This is an open access article distributed under the Creative Commons Attribution \\ License, which permits unrestricted use, distribution, and reproduction in any medium, provided the original work is properly \\ cited.
}

This paper entitled "Cashew nut shell waste: availability in small-scale cashew processing industries and its fuel properties for gasification" has been retracted as it was submitted for publication without the acknowledgement of Biofuel Laboratory, CIAE Bhopal. Additionally, it was found to contain a substantial amount of material from the Proceeding, S. Gangil, A. K. Dubey, Thermo Gravimetric Properties of Cashew Shell Cake Proceedings of the 44th Annual Convention \& Symposium of ISAE, New Delhi, India, IARI, pp. 4.17, January 2010 [1].

\section{References}

[1] A. Mohod, S. Jain, and A. Powar, "Cashew nut shell waste: availability in small-scale cashew processing industries and its fuel properties for gasification," ISRN Renewable Energy, vol. 2011, Article ID 346191, 4 pages, 2011. 